\title{
Growth and development of Alfalfa depending on the type of nitrogen nutrition
}

\author{
Marina Yu. Kozyreva ${ }^{1}$, Larisa Zh. Basieva ${ }^{1, *}$, Al-Azawi Nagham Majeed Hameed ${ }^{2}$, Alda \\ $K h$. Chibirova ${ }^{3}$, and Khetag M. Khetagurov ${ }^{4}$ \\ ${ }^{1}$ Gorsky State Agrarian University, Department of Land Management and Ecology, 362040 \\ Vladikavkaz, Russia \\ ${ }^{2}$ University of Baghdad, Agricultural Engineering Sciences College, 10001 Baghdad, Iraq \\ ${ }^{3}$ South Ossetian State University named after A.A. Tibilov, Department of Biology, 100001 \\ Tskhinval, Republic of South Ossetia \\ ${ }^{4}$ North-Ossetia State University after K.L. Khetagurov, Department of Anatomy, Physiology and \\ Botany, 362025 Vladikavkaz, Russia
}

\begin{abstract}
Mineral and symbiotrophic types of nitrogen nutrition of plants were compared in experiments with the blue-hybrid alfalfa. Variants with seed inoculation by high-mountain strains of nodule bacteria (In-1800 and $\mathrm{N}_{30}+\mathrm{In}$ ) had the maximum height of plants during all experimental years (40$70 \mathrm{~cm}$ ), which is explained by the better nitrogen provision of plants. At the same time, the effect of the mineral forms of nitrogen appeared only in the year of sowing at the beginning of the growing season to the first mowing, in the future the differences between these options were neutralized. The foliage intensity of plants was in the range of $41.4-54.8 \%$, increasing due to the improved availability of biologically bound nitrogen in plants. Mineral forms of nitrogen reduced plants' foliage coverage in all experimental years, however, this decrease was noted only in the initial periods of vegetation. The maximum indicators of foliage coverage were noted in the In-1800 variant. By the end of the third year of crops use, the plant stand density was 980-1100 thousand units/ha, and the total thinning of alfalfa crops reached $45-51 \%$. At the same time, the symbiotrophic type of nitrogen nutrition made it possible to significantly increase the competitiveness of plants, which ultimately affected the persistence of the crop density.
\end{abstract}

\section{Introduction}

The relevance of the study of legumes and, in particular, of alfalfa, is determined by their high nutritional and important agricultural value [1-3]. Crops of perennial legumes are of particular value in Russia due to implementation of a federal law on organic production and transition to organic farming. High requirements for soil fertility in organic farming determine the widespread use of legumes and their unique ability to fix molecular atmospheric nitrogen in symbiosis with rhizospheric microorganisms [4-6].

\footnotetext{
* Corresponding author: ironlag@mail.ru
} 
The activation of processes and an increase in the volumes of symbiotic nitrogen fixation require researchers to study the factors limiting this process in each agroclimatic region and the impact of resource-saving, environmentally friendly methods in more detail [7-9]. At the same time, plants and microorganisms must be studied as a single system, as they are interconnected by numerous bonds formed in the course of evolution that respond to any changes in the biocenosis [10-11].

Phenological and biometric indicators of crops are a specific indicator of the compliance of environmental factors with the requirements of culture's biology. The insufficient, as well as the excess supply of plants with life supporting factors negatively affects initially their growth and development, and subsequently - their productivity.

This article discusses the impact of the type of nitrogen nutrition on the phenological and biometric indicators of alfalfa, in particular, the calendar dates of the onset of phenological phases of development, the dynamics of plant height and foliage coverage, and the dynamics of plant density.

\section{Materials and methods}

The studies were carried out during several years (2017-2019) on the territory of the educational-scientific-production department of the Gorsky State Agrarian University. The soil cover is leached chernozem, pebbled from a depth of $60-80 \mathrm{~cm}$ and characterized by an average humus content of 4.5-6.0\% (according to Tyurin), easily hydrolyzed nitrogen - about $80 \mathrm{mg} / \mathrm{kg}$, which is increased (according to Konev), mobile phosphorus - $90 \mathrm{mg} / \mathrm{kg}$, which is average (according to Chirikov), exchangeable potassium - $150 \mathrm{mg}$, which is high (according to Chirikov), $\mathrm{pH}_{\text {salinity }}$ - 5.9-6.3.

The objects of the research were: the blue-hybrid alfalfa (Medicago varia Mart.), standard Vega 87 variety, cultivated in the North Caucasus region, and local races of nodule bacteria of the Sinorhizobium genus, which we selected from the rhizospheric part of alfalfa plants at various altitudes in the environmental conditions of the Republic of North Ossetia-Alania [12-13].

In the field experiment, a pre-sowing inoculation of seeds was carried out using an inoculum based on wild races of nodule bacteria selected in high altitude conditions (1800 meters above sea level, Zaramag village, Republic of North Ossetia-Alania), as well as an industrial strain of rhizotorfin 425a brand (All-Russian Research Institute of Agricultural Microbiology, St. Petersburg), recommended by researchers in these climatic conditions [1415]. Starting doses of mineral forms of nitrogen were introduced annually: $30 \mathrm{~kg} / \mathrm{ha}$ for the pre-sowing cultivation, $30 \mathrm{~kg}$ in the early spring crop of the $2^{\text {nd }}$ year of plant life and $30 \mathrm{~kg}$ in the early spring crop of the $3^{\text {rd }}$ year of plant life.

Experiment design and justification:

1. Control experiment - the natural fertility of the soil.

2. In-1800 - pre-sowing inoculation of seeds with inoculum of strains of nitrogen-fixing bacteria selected in high altitude conditions, in order to study the issues of their introduction and determine competitiveness in plain and more favorable environmental conditions.

3 Strain $425 \mathrm{a}$ - pre-sowing inoculation of seeds with an industrial strain of rhizotorfin, for a comparative assessment with local strains of rhizobia and wild alpine races of nodule bacteria.

4. $\mathrm{N}_{30}$ - annual introduction of starting doses of nitrogen fertilizers, in order to study the symbiotic activity of legume-rhizobia cenosis in the presence of mineral forms of nitrogen.

5. $\mathrm{N}_{30}+\mathrm{In}-$ the use of pre-sowing seed inoculation with alpine strains of nitrogen-fixing bacteria against the background of annual starting doses of mineral forms of nitrogen, in order to study the possibility of sharing these agrotechnical methods. 
Methods for conducting field experiment and statistical data processing are generally accepted.

\section{Results and discussion}

In the study of forage grasses, and, in particular, alfalfa, important characteristics are their biometric indicators. Plant height characterizes the qualitative and quantitative state of crops and allows farmers to judge both the level of agricultural technology and the magnitude of the formed biomass (Table 1).

Table 1. Dynamics of the height of alfalfa plants till the mowing ripeness depending on the type of nitrogen nutrition $(\mathrm{cm})$

\begin{tabular}{|c|c|c|c|c|c|c|}
\hline \multirow[b]{2}{*}{ Mowing } & \multicolumn{5}{|c|}{ Experiment variants } & \multirow[b]{2}{*}{$\mathrm{HCP}_{05}$} \\
\hline & Control & In-1800 & $\begin{array}{c}\text { Strain } \\
425 a\end{array}$ & $\mathbf{N}_{30}$ & $\mathbf{N}_{30}+\mathbf{I n}$ & \\
\hline \multicolumn{7}{|c|}{2017 (sowing year) } \\
\hline $1^{\text {st }}$ mowing & 43 & 48 & 47 & 50 & 52 & 1.9 \\
\hline $2^{\text {nd }}$ mowing & 45 & 53 & 51 & 47 & 52 & 1.7 \\
\hline \multicolumn{7}{|c|}{$2018\left(2^{n d}\right.$ year of life $)$} \\
\hline $1^{\text {st }}$ mowing & 61 & 69 & 66 & 65 & 70 & 1.8 \\
\hline $2^{\text {nd }}$ mowing & 47 & 57 & 52 & 48 & 55 & 2.1 \\
\hline $3^{\text {rd }}$ mowing & 38 & 45 & 41 & 38 & 45 & 1.6 \\
\hline \multicolumn{7}{|c|}{2019 ( $3^{r d}$ year of life) } \\
\hline $1^{\text {st }}$ mowing & 52 & 55 & 55 & 55 & 56 & 1.8 \\
\hline $2^{\text {nd }}$ mowing & 45 & 48 & 47 & 46 & 49 & 1.7 \\
\hline $3^{\text {rd }}$ mowing & 37 & 40 & 39 & 38 & 40 & 1.4 \\
\hline
\end{tabular}

The results of our experiments showed that due to the intensification of the symbiotic relationship of alfalfa with nitrogen-fixing bacteria, the processes of plant growth and development improved. Thus, the minimum plant height in all experimental years was observed in plants of the control variant - which amounted to $37-61 \mathrm{~cm}$. The introduction of starting doses of nitrogen fertilizers increased the plant height by $3-7 \mathrm{~cm}$ only at the beginning of the growing season by the time of the first mowing, and subsequently the height indicators were at the level of the control variant.

In all other experimental variants, where active strains of rhizobia were used, the plants exceeded the control variant in all years from 2 to $10 \mathrm{~cm}$, apparently due to the better nitrogen supply, both minerally and biologically related.

The lowest plant height in the experiment was observed in the first year of plant life (43$53 \mathrm{~cm})$, the highest - in the second year of life $(38-70 \mathrm{~cm})$, which is explained by the morphological features of alfalfa's growth and development.

In crops of the third year of plant life, the differences between the experimental variants evened out noticeably and were within $3-4 \mathrm{~cm}$, and the plant height reached $37-56 \mathrm{~cm}$, increasing as the nitrogen supply improved.

Variants with seed inoculation with alpine strains of nodule bacteria (In-1800 and $\mathrm{N}_{30}+$ In) had the maximum height of plants in all experimental years $(40-70 \mathrm{~cm})$, which is explained by the better provision of plants with nitrogen. At the same time, the effect of the mineral forms of nitrogen appeared only in the year of sowing at the beginning of the growing season to the first mowing, in the future the differences between these options were neutralized.

Analyzing data on plant height, it is necessary to note a regular decrease in this indicator during the year with each mowing. This circumstance is also explained in terms of plant life strategy, in which the main goal is the formation of generative organs. Therefore, the desire 
of plants to get to the flowering phase, on the one hand, leads to a slowdown in the growth processes of plants, and on the other hand, as mentioned above, to reduction of the intramowing periods.

An important qualitative characteristic of forage grasses is the foliage coverage of plants (Table 2). Content of nitrogen and, accordingly, protein is two times higher in the leaves than in the stems. Therefore, this indicator primarily affects the nutritional value of the received fertilizer.

Table 2. Dynamics of the foliage coverage of alfalfa plants till the mowing ripeness depending on the type of nitrogen nutrition (\%)

\begin{tabular}{|l|c|c|c|c|c|c|}
\hline \multirow{2}{*}{ Mowing } & \multicolumn{7}{|c|}{ Experiment variants } & \multirow{2}{*}{ HCP } \\
\cline { 2 - 6 } & Control & In-1800 & $\begin{array}{c}\text { Strain } \\
\mathbf{4 2 5 a}\end{array}$ & $\mathbf{N}_{\mathbf{3 0}}$ & \multirow{2}{*}{$\mathbf{N}_{\mathbf{3 0}}+\mathbf{I n}$} & \\
\hline \multicolumn{7}{|c|}{$\mathbf{2 0 1 7}$ (sowing year) } \\
\hline $1^{\text {st }}$ mowing & 49,2 & 54,1 & 53,4 & 48,8 & 48,7 & 1.1 \\
\hline $2^{\text {nd }}$ mowing & 50,1 & 54,8 & 53,8 & 50,3 & 52,9 & 1.6 \\
\hline \multicolumn{7}{|c|}{$\mathbf{2 0 1 8}\left(2^{\text {nd }}\right.$ year of life) } \\
\hline $1^{\text {st }}$ mowing & 43,2 & 47,3 & 45,8 & 43,1 & 45,8 & 1.8 \\
\hline $2^{\text {nd }}$ mowing & 45,5 & 49,1 & 47,2 & 44,9 & 48,9 & 1.9 \\
\hline $3^{\text {rd }}$ mowing & 48,6 & 51,8 & 50,6 & 48,2 & 51,9 & 2.1 \\
\hline \multicolumn{7}{|c|}{$\mathbf{2 0 1 9}\left(3^{\text {rd }}\right.$ year of life) } \\
\hline $1^{\text {st }}$ mowing & 41,4 & 44,3 & 43,5 & 41,5 & 43,4 & 2.2 \\
\hline $2^{\text {nd }}$ mowing & 42,7 & 45,1 & 44,2 & 42,9 & 45,3 & 2.1 \\
\hline $3^{\text {rd }}$ mowing & 44,5 & 47,6 & 46,3 & 44,6 & 47,8 & 2.2 \\
\hline
\end{tabular}

In our experiments, the foliage coverage of plants was in the range of $41.4-54.8 \%$, it was increasing as the plants' supply with biologically bound nitrogen improved. Moreover, in the year of sowing, the foliage of plants was significantly higher than in the subsequent years.

Mineral forms of nitrogen reduced the foliage coverage of plants in variants with $\mathrm{N}_{30}$ and $\mathrm{N}_{30}+$ In in all experimental years, however, this decrease was observed only in the initial periods of vegetation during the action of starting doses of nitrogen fertilizers. In subsequent periods, this indicator was aligned with the corresponding variants (control and In-1800).

The maximum indicators of plants' foliage coverage were observed in the variant with pre-sowing seed inoculation with alpine inoculum of nodule bacteria (In-1800) and ranged from 44.3 to $54.8 \%$, depending on the year of use of the crops. The older the crops, the more powerful the plant stems are and their share in the total biomass increased significantly.

One of the unfavorable biological characteristics of alfalfa is considered to be the strong thinning of crop stands both in the winter-spring period and during the growing season. However, this fact allows the surviving plants to make better use of solar energy, to grow stronger, to form new stems and, ultimately, not to reduce the yield of aerial mass.

One of the reasons that can affect the thinning of crops, in our opinion, is the poor supply of plants with nitrogen (Table 3). The density of seedlings in the experiment was about 2 million units/ha with an insignificant difference between the variants. By the end of the first year of vegetation, the thinning rate was $8-10 \%$, while the differences between the varieties were within the experimental error. 
Table 3. Dynamics of the standing density of alfalfa plants, depending on the type of nitrogen nutrition (thousand units/ha)

\begin{tabular}{|c|c|c|c|c|c|c|}
\hline \multirow[b]{2}{*}{ Calculation period } & \multicolumn{5}{|c|}{ Experiment variants } & \multirow[b]{2}{*}{$\begin{array}{l}\mathrm{HCP}_{0} \\
5\end{array}$} \\
\hline & Control & In-1800 & $\begin{array}{c}\text { Strain } \\
425 a\end{array}$ & $\mathbf{N}_{30}$ & $\mathbf{N}_{30}+\mathbf{I n}$ & \\
\hline \multicolumn{7}{|c|}{2017 (sowing year)) } \\
\hline $\begin{array}{l}\text { beginning of } \\
\text { vegetation }\end{array}$ & 1980 & 2000 & 2000 & 1980 & 2000 & 44 \\
\hline end of vegetation & 1810 & 1840 & 1840 & 1800 & 1820 & 36 \\
\hline \multicolumn{7}{|c|}{$2018\left(2^{\text {nd }}\right.$ year of life $)$} \\
\hline $\begin{array}{l}\text { beginning of } \\
\text { vegetation }\end{array}$ & 1650 & 1700 & 1690 & 1640 & 1690 & 48 \\
\hline end of vegetation & 1430 & 1520 & 1490 & 1430 & 1510 & 55 \\
\hline \multicolumn{7}{|c|}{2019 ( $3^{\text {rd }}$ year of life) } \\
\hline $\begin{array}{l}\text { beginning of } \\
\text { vegetation }\end{array}$ & 1210 & 1320 & 1280 & 1210 & 1310 & 63 \\
\hline end of vegetation & 980 & 1100 & 1060 & 980 & 1090 & 69 \\
\hline
\end{tabular}

Note: * for the analysis convenience, the crop density indicators are rounded up to 10 thousandths

The thinning increased in the winter-spring period and, by the beginning of the growing season of the second year, the plant stand density was 1640-1700 thousand units/ha. Variants with seed inoculation with active strains of rhizobia compared with the control variant and the option using only starting doses of mineral forms of nitrogen had significantly better indicators. By the end of the growing season of the second year of use of crops, the thinning reached $24.0-28.5 \%$.

The thinning increased by another $10-11 \%$ in the next winter-spring period and during the growing season of the third year - by another $11 \%$. As a result, by the end of the use of alfalfa crops, the plant stand density was 980-1100 thousand units/ha, and the total crop thinning reached $45-51 \%$. It should be noted that the symbiotrophic type of nitrogen nutrition significantly increased the competitiveness of plants, which ultimately affected the persistence of the crops' density.

\section{Conclusion}

The main goal of plant life strategy is the formation of generative organs. Reducing the length of daylight hours during the growing season and the desire of plants for the onset of the flowering phase, on the one hand, lead to a slowdown in plant growth processes (plant height), and on the other hand - to an earlier onset of mowing ripeness.

Variants with seed inoculation with alpine strains of nodule bacteria (In-1800 and N30 + In) had the maximum plant height in all experimental years $(40-70 \mathrm{~cm})$, which is explained by better provision of plants with nitrogen. At the same time, the effect of the mineral forms of nitrogen appeared only in the year of sowing at the beginning of the growing season to the first mowing, in the future the differences between these options were neutralized.

The foliage coverage of plants was in the range of $41.4-54.8 \%$, it was increasing as the plants' supply with biologically bound nitrogen improved. Mineral forms of nitrogen reduced the foliage coverage in variants $\mathrm{N}_{30}$ and $\mathrm{N}_{30}+$ In in all experimental years, however, this decrease was observed only in the initial periods of vegetation during the action of starting doses of nitrogen fertilizers. The maximum indicators of plants' foliage were observed in the variant with pre-sowing seed inoculation with alpine inoculum of nodule bacteria (In-1800).

By the end of the third year of use of crops, the plant stand density was 980-1100 thousand units/ha, and the total thinning of alfalfa crops reached $45-51 \%$. At the same time, the 
symbiotrophic type of nitrogen nutrition made it possible to significantly increase the competitiveness of plants, which ultimately affected the persistence of the density of crops.

\section{References}

1. A. T. Farniev, A. Kh. Kozyrev, A. R. Pukhaev, A. A. Sabanova, Kh. P. Kokoev, Assotsiativnye risobakterii $i$ biologizatsiya tehnologiy vozdelyvaniya sel'skohozyajstvennyh kultur $v$ RSO-Alaniya [Associative rhizobacteria and biologization of crop cultivation technologies in North Ossetia-Alania] (Gorsky State Agrarian University, Vladikavkaz, 2017)

2. N. O. Bolatati, L. Zh. Basieva, A. Kh. Kozyrev, Innovatsionnye tehnologii v rastenievodstve $i$ ekologii [Proceedings of international scientific-practical conference Innovative technologies in crop production and ecology], 111 (Gorsky State Agrarian University, Vladikavkaz 2017)

3. A. T. Farniev, A. Kh. Kozyrev, Zemledelie 1, 9 (2004)

4. A. Kh. Kozyrev, P. V. Alborova, A. A. Sabanova, Proceedings of the Gorsky State Agrarian University 49, 71 (2012)

5. A. T. Farniev, A. Kh. Kozyrev, A. A. Sabanova, Kh. P. Kokoev, D. K. Khanaeva, L. M. Bazaeva, P. V. Alborova, Indo American Journal of Pharmaceutical Sciences 6, 8956 (2019). DOI: 10.5281/zenodo.2669529

6. D. N. Doev, V. P. Tsotsieva, L. G. Basieva, Science Almanac of Black Sea Region Countries 4, 34 (2015)

7. D. N. Doev, A. Kh. Kozyrev, Proceedings of the Gorsky State Agrarian University 51, 248 (2014)

8. A. T. Farniev, A. Kh. Kozyrev, R. B. Temiraev, P. V. Alborova, Proceedings of the Gorsky State Agrarian University 48, 36 (2011)

9. V. P. Tsotsieva, L. Zh. Basieva, A. Kh. Kozyrev, Proceedings of the Gorsky State Agrarian University 52, 57 (2015)

10. L. G. Dzhikaeva, L. Zh. Basieva, Proceedings of the Gorsky State Agrarian University 49, 23 (2012)

11. N. S. Ovcharenko, A. Kh. Kozyrev, Mikromicety aromaticheskih i lekarstvennyh rastenij Kryma [Micromycetes of aromatic and medicinal plants of Crimea] (Federal State Budgetary Educational Institution Higher Education Gorsky State Agrarian University, Vladikavkaz, 2018)

12. M. Yu. Kozyreva, L. Zh. Basieva, Vestnik Altajskogo Gosudarstvennogo Agrarnogo Universiteta 5, 19 (2020)

13. A. Kh. Kozyrev, S. A. Bekuzarova, N. O. Bolatati, M. Yu. Kozyreva, E. B. Kalashnikova, Patent Russian Federation No. 2670169 A method for maintaining the activity of nodule bacteria during introduction (2018)

14. A. Kh. Kozyrev, M. A. Pliev, D. I. Darchieva, Fodder Production 8, 28 (2007)

15. A. Kh. Kozyrev, A. T. Farniev, Fodder production 7, 28 (2009) 